\title{
Evaluation of the Physical and Chemical Quality of Moroccan Cow Raw Milk in Dairy Herds Located in the Beni Mellal Region
}

\author{
Rachid Hnini, Lhou Ouhida, Mohammed Chigr, Mohamed Merzouki, Ahmed Gammouh, \\ Mohamed Najimi, Fatiha Chigr
}

\begin{abstract}
The main objectives of the present study were to evaluate the physicochemical quality of raw cow milk produced in Beni Mellal region, one of the major milk production areas in Morocco located in the North-Centre of Morocco to evaluate the characteristics of the raw milk produced and also to evaluate effects nutritional and breeding factors on chemical and physical factors. Physicochemical quality of raw milk was determined by assessing the analysis of "Fat Content", "Protein Content", "Total Solids", "Solids No-Fat", "Acidity", "Brix", "Density", "Temperature" and "Alcohol Test", using recognized standardized methods and infrared methods for better assessing of characteristics (fat, protein, total solids and no-fat solids contents). The results obtained from this study showed a variability average in the physicochemical quality of raw milk between the different farms where the samples have been collected. Despite this variability, the fat and protein contents displayed high levels which by consequent is considered as high economic value for the producers and for the manufactures allowing in final the consumer to dispose of good nutritional product in the market. Furthermore, the values concerning temperature, $\mathrm{pH}$ and Dornic acidity do not exceed the recommended values attesting on the good hygienic quality of the raw cow milk produced in this geographical area in Morocco. The present findings complete our previous investigations made in the same geographical area but in other different locations and extend our knowledge on the evolution of the quality of raw cow milk produced in this large area.

Index Terms - Raw cow milk, milk quality, physical and chemical analysis, Beni Mellal areas, Morocco.
\end{abstract}

\section{INTRODUCTION}

In Morocco, since the launch of the dairy plan in 1975

Rachid Hnini, Laboratory of Biological Engineering, Pathology and Functional Biology Team, Sultan Moulay Slimane University, FST, PO.Box: 523, 23000 Beni Mellal, Morocco.

Lhou Ouhida, Laboratory of Biological Engineering, Pathology and Functional Biology Team, Sultan Moulay Slimane University, FST, PO.Box: 523, 23000 Beni Mellal, Morocco.

Mouhamed Chigr, Chemistry science department, Sultan Moulay Slimane University, FST, Beni Mellal, Morocco.

Mouhamed Merzouki, Laboratory of Biological Engineering, Pathology and Functional Biology Team, Sultan Moulay Slimane University, FST, PO.Box: 523, 23000 Beni Mellal, Morocco.

Mouhamed Gammouh, Sultan Moulay Slimane University, FST, PO.Box: 523, 23000 Beni Mellal, Morocco.

Mouhamed Najimi, Laboratory of Biological Engineering, Pathology and Functional Biology Team, Sultan Moulay Slimane University, FST, PO.Box: 523, 23000 Beni Mellal, Morocco.

Fatiha Chigr, Laboratory of Biological Engineering, Pathology and Functional Biology Team, Sultan Moulay Slimane University, FST, PO.Box: 523, 23000 Beni Mellal, Morocco. (setting up of a production, collection and processing structure), this sector has grown significantly from 521.6 million liters in 1975 to 2.6 billion liters in 2015 [1]. The development of this sector is in line with the goals of the new Moroccan agricultural strategy (the Moroccan Green Plan) for food self-sufficiency in horizon of 2020. It concerned seven basic alimentary products essential to the Moroccan diet where milk is an essential one [2]. For this reason, Morocco has re-launched the program-contract signed by the sector and the public authorities in 2015 , which consequently foresees that the kingdom goes from a collection of 2.4 billion liters in 2013 to 4 billion in 2020, an increase of 1.55 billion liters compared to 2015 and a turnover of 23 billion dirhams [1]. This 2015-2020 national program-contract aims also to raise the average annual per capita consumption to 90 liters [1]. However, this challenge concerning milk quantities to produce poses the problem of the quality of raw milk produced. Thus, if the produced quantities of milk are today in general satisfactory because of the great efforts that made by Morocco in this context (encouraging milk production principally cow milk) various problems associated to the quality standards which are very hard to meet [3-8] still exist which constitutes a challenge for the agro-alimentary sector especially dairy industry in the county [9-10]. Among these problems, we cited two major factors. The first one is directly associated with the heterogeneity of raw milk's compositions, influenced by several factors such as the geographical area, breeding, nutritional factors and climate conditions [8-11] while the second one is appeared in difficulty to respect hygienic procedures leading to a significant microbial charge touching the hygienic quality and representing in this a serious concern for human health [9-10, 12].

The quality levels are the main and serious problems that encounter always in dairy industry sector. So, when quality of milk is discussed, various subjective interpretations could be adopted in accordance with the defined criteria. Thus, the quality of milk will tend to vary in dependence to the individual and the levels within the industry. In this regard, some tend to evaluate milk relying on organoleptic or even visual characteristics (especially upstream and downstream, i.e. farmers and consumers), whereas others will utilize quantitative analytical criteria, such as protein and fat contents or the contamination level of milk by microorganisms (dairy processing) [13].

In dairy industry, chemical and physical criteria as well as 
hygienic criteria are the known three fundamental methods for describing milk quality. Chemical criteria are in general correlated with milk nutrient contents according to [14]. Thus, assessing the contents of protein, fat, and to a lesser degree calcium in milk provides the nutritional value of the product and its use in dairy processing is performed by developed laboratory analytical methods in dairy industry while the physical criteria are most many times associated with the acidity, density and temperature of the milk [4, 14]. These last physical criteria i.e. acidity, density and temperature, will be indicative indirectly on the hygienic status of the milk [13] in relation to microbiological aspects (notably potential pathogens) [14-17].

This study aimed to extend our knowledge concerning the physico-chemical composition of the raw cow milk produced in this important agricultural area as this raw milk, supplies three milk manufactories, two of them are majors in the field. The quality, notably fat and protein contents, is in this sense important as the milk could be processed as pasteurized milk, UHT milk or derived products.

\section{MATERIAL AND METHODS}

\section{A. Sampling zones}

This work was performed in different irrigated perimeters of the Beni Mellal region, located in the north-centre of Morocco (Figure 1). These areas are situated West-North (area 1), North-West (area 2), West (area 3), and North (area 4) to Beni Mellal city and have been chosen for their potential milk production. Almost of the areas investigated are situated in Tadla Plain. The plain parts are well developed and the agriculture is generally based on irrigation methods and many farms have developed their activities inside them and there is a large milk production from cows and goats [9-10].

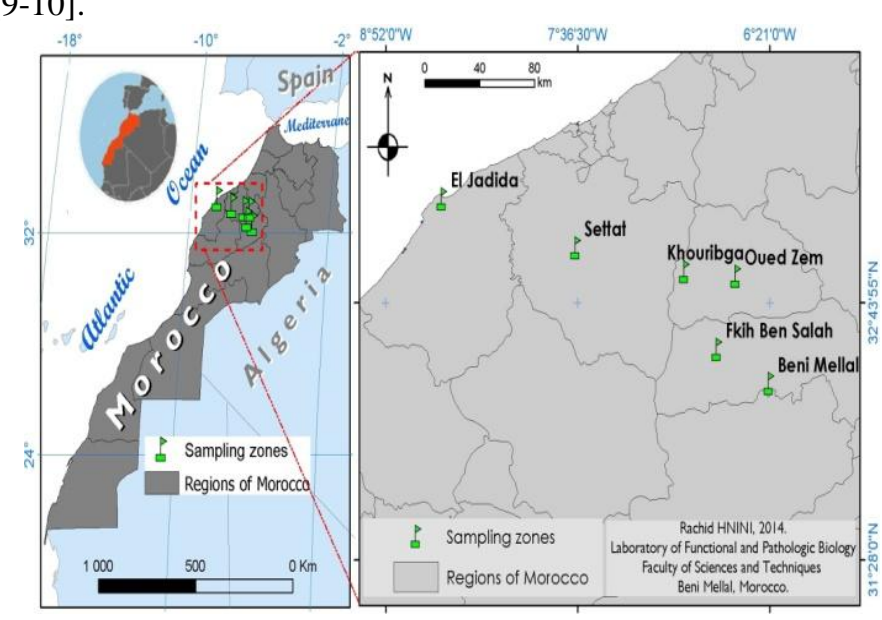

Figure 1: Presentation of sampling zones
In general, the Tadla region climate is well-known to be semi-arid with a dry season from April to October and it is also characterized by a rainy season from November to March [18]. The annual cumulative rainfall varies from 149 to 397 mm between 2000 and 2013 while the seasonal variations of temperature are significant with a maximum in August of 46 ${ }^{\circ} \mathrm{C}$, a minimum in January of $-6{ }^{\circ} \mathrm{C}$ and an annual average of $20 \circ \mathrm{C}[19]$.

\section{B. Sampling preparation}

A total of 100 samples of cow raw milk was collected into sterile bottles (about $1000 \mathrm{ml}$ ) for physicochemical analysis from seventeen farms randomly selected in these areas and transported immediately in thermos-cool boxes (at $4^{\circ} \mathrm{C}$ ) to Biological Engineering Laboratory, Sultan Moulay Slimane University during a period extended from January to June. All the sampling has been made at the morning and afternoon milking times and all physicochemical parameters were directly determined on the day or the night of sampling.

\section{Physicochemical analysis}

In general, after sample collection, the temperature of the milk is directly measured in place with a thermometer. Once raw milk samples arrived at laboratory in an insulated cooler containing ice cubes (thermos-cool boxes $\left(\right.$ at $\left.4{ }^{\circ} \mathrm{C}\right)$ ). The $\mathrm{pH}$ is immediately measured using an Orion Reseach $\mathrm{pH}$-meter after calibration at $\mathrm{pH} 7.02$ and 4.00 by soaking in a small volume of milk taken from a beaker [20] while titratable acidity is measured by titration with $1 \mathrm{~N} \mathrm{NaOH}$ in the presence of phenophthalein and acidity of milk was expressed in degrees Doronic $\left({ }^{\circ} \mathrm{D}\right)$ which is equivalent to a grade of $0.1 \mathrm{~g}$ of lactic acid/L of milk [21]; the milk density is determined using a thermo-lacto- densimeter. It is reduced to $20^{\circ} \mathrm{C}$ by the following formula: corrected density $=$ read density +0.2 (milk temperature $-20^{\circ} \mathrm{C}$ ).

When the chemical criteria is considered, the fat content is firstly determined by the acid-butyrometric method of Gerber [22], which consists of an attack of milk with sulfuric acid and separation by centrifugation in the presence of isoamyl alcohol of the released fat [23-24] while the determination of the levels of proteins, fat, total solids, solids-non-fat is carried out using the milkoscan ${ }^{\mathrm{TM}}$ minor apparatus calibrated to official methods to determine the protein level (Kjeldal method), fat content (Gerber method) and total solids (desiccation method). The results are displayed directly on the screen or printed out; the results are expressed $g / 100 \mathrm{~g}$.

\section{RESULTS}

The essential of results of the physicochemical analysis of raw cow's milk produced in different studied areas of Beni Mellal region are presented in Table $\mathbf{1}$ 
Table 1: Physicochemical analyzes average of raw milk obtained from different areas in Beni Mellal region.

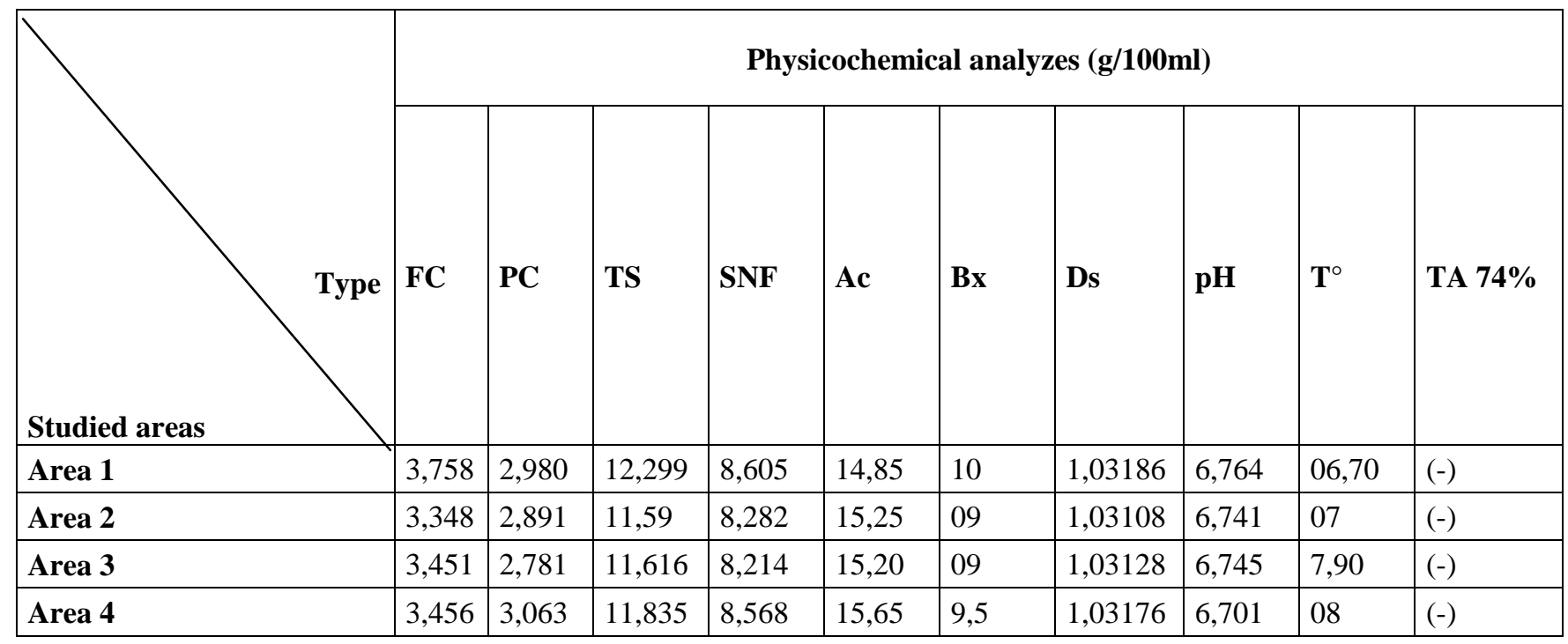

FC: fat content, PC: protein content, TS: total solids, SNF: solids no-fat, Ac: acidity, Bx: brix, Ds: density, $\mathrm{T}^{\circ}$ : temperature, AT: alcohol test, (-): negative test.

The results obtained from this study show a variability average in the nutritional quality of raw milk between the different studied areas. In this regard, the milk fat content average obtained was ranged from the high value of 37.6 obtained in the West-North to the low value of $33.4 \mathrm{~g} / \mathrm{l}$ recorded in the North-West areas. The other graded values: about 34.51 and $34.56 \mathrm{~g} / \mathrm{l}$ are evidenced in West and North areas, respectively. Moreover, the average values recorded of milk protein content was respectively about 29.8 (West-North area), 28.9 (North-West area), 27.8 (North area) and $30.6 \mathrm{~g} / \mathrm{l}$ (North area) whereas the total solids level was around 122.9, 115.9, 116.1 and $118.3 \mathrm{~g} / \mathrm{l}$, in the West-North area, North-West area, West area and the North area respectively. Finally, an average of 86.0, 82.8, 82.1 and $85.6 \mathrm{~g} / \mathrm{l}$ was found in the West-North area, North-West area, West area and the North area respectively for solids no-fat. Of note, the brix average rate oscillated between 09 to $10 \%$ for all studied areas.

Concerning physical criteria, the result obtained of milk Dornic acidity collected from the main fourth areas investigated was as follows: $14.85,15.25,15.20$ and $15.65 \mathrm{D}^{\circ}$, respectively. Moreover, the ionic acidity $(\mathrm{pH})$ is oscillated from 6.70 to 6.76 . The measurement of milk density in these regions ranged generally from 1.0310 to 1.0318 while temperature of all samples collected from bulk milk was in the range of 06 to $08{ }^{\circ} \mathrm{C}$. All milk samples tested for alcohol testing were normal at $74 \%$.

\section{DISCUSSION}

In general, the rational feeding of dairy cows has a major influence on both the quantitative and quality production of milk for industrial uses. The value or industrial quality of milk can be expressed by all the properties and physicochemical, biological and organoleptic characteristics required for ensure the production of high value dairy products commercial [25]. In this study, the findings retained from different areas investigated, revealed the presence of different individual values with regard to chemical and physical characteristics, depending on the area investigated. Concerning the chemical results obtained, the milk fat content average was ranged from 33.4 to $37.6 \mathrm{~g} / \mathrm{l}$. Moreover, the average values recorded for milk protein content are between 27.8 and $30.6 \mathrm{~g} / \mathrm{l}$ whereas for the total solids they are between 115.9 and $122.9 \mathrm{~g} / \mathrm{l}$ and between 82.1 and $86.0 \mathrm{~g} / \mathrm{l}$ for solids no-fat. Finally, the brix rate oscillated between 09 and $10 \%$ for all studied areas. These results are due particularly to various major factors like the extensive utilization of concentrate type of feeding given to cows [26-27] an/or the farming practices used in these regions [7-8].

In general, the fat result obtained is situated over the limit range adopted by AFNOR for fat standard (28.5 to $32.5 \mathrm{~g} / \mathrm{l}$ ) [23]. This is of high economic importance for producers that are reattributed according principally to this criterion. This also reflects the efforts made by these producers to have highly standard raw milk by adopting good breeding practices notably in relation to nutritional aspect. Below this threshold, dairy industries in Morocco apply penalties on quality [4]. The comparison of our findings in this study with those previously reported by Bassbassi et al.[28] from February to April in some cooperatives and farms in region of Fkih-ben-salh (West-North to Beni Mellal city), Kssiba (East to Beni Mellal city) (Beni Mellal areas) and Kalaa region especially for solids no-fat, protein and fat contents stay superior that what we found her particularly in farms case from Fkih-ben-salh: (fat: $41.05 \mathrm{~g} / \mathrm{kg}$, protein: $33.78 \mathrm{~g} / \mathrm{kg}$ and solids no-fat: $96.81 \mathrm{~g} / \mathrm{kg}$ ), Kssiba: (fat: $41.16 \mathrm{~g} / \mathrm{kg}$, protein: $33.02 \mathrm{~g} / \mathrm{kg}$ and solids no-fat: $96.67 \mathrm{~g} / \mathrm{kg}$ ) and from Kalaa: (fat: $38.28 \mathrm{~g} / \mathrm{kg}$, protein: $32.94 \mathrm{~g} / \mathrm{kg}$ and solids no-fat: $95.36 \mathrm{~g} / \mathrm{kg})$.

This notable difference showed a variability of nutritional milk quality between regions and milk farms. This variation is due to the geographical difference that leads to the variation of climatic conditions and the ways to feed livestock and is also associated to breeding conditions adopted by the farms. 
According to our previous study, the heterogeneity of raw milk's compositions is also influenced by the geographical area, breeding, climate conditions and nutritional factors [9-10]. Additionally to nutritional supply, the climate is considered to be a significant factor that has an effect on the variation between the composition of the milk fat content as well as the dry milk extracts. According to Gonzalo et al.[29], the water content of milk decreases in cold season and therefore its dry matter increases. Of note, the results given in this study are the average of measurements made a period of the year extended from January to June which could not reveal seasonal variations.

When milk composition quality in Morocco was considered, our findings for fat content in the studied areas remained higher than previous contents reported by Labioui et al.[20] in Mnasra region (31.5 g/l) as for total solids (117.5 $\mathrm{g} / \mathrm{l})$. Our findings for protein content showed less levels in comparison with those reported in Rabat-Sale region (a maximum of $32.7 \mathrm{~g} / \mathrm{kg}$ and a minimum of $30.8 \mathrm{~g} / \mathrm{kg}$ ) while the fat content in this region remained also in most cases higher than what has been shown in our investigation [4]. This could be associated with a food system based on concentrates using more forage in the energy balance in the farms investigated in Rabat-Sale region [4]. Generally, the importance of the food type specified to dairy cows must be taken into consideration; for example, during drought periods, milk producers try to find alternatives to maize silage, especially in dry conditions. Thus, the cereal-legume bi-crop silage, sorghum or alfalfas represent interesting solutions. The sorghums utilization instead of maize silage have been enabled to decreased daily milk when sorghum silage was over $65 \%$ of the forages and the fat content have been also increased (2.6 to $4.4 \mathrm{~g} / \mathrm{kg}$ ) according to Rouille et al.[30].

The physical criteria are measured in order to evaluate milk quality [14]. The degree of acidity indicates freshness and determines technological suitability of milk [31-32]. The acidity obtained of milk collected from the different areas investigated was ranged from 14.85 to $15.65 \mathrm{D}^{\circ}$. In general, these findings were situated in the values reported by Hamama [33] and AFNOR [22], which showed that the raw milk acidity is normally between 15 and $18^{\circ} \mathrm{D}$ for fresh milk. Moreover, the ionic acidity $(\mathrm{pH})$ is oscillated from 6.70 to 6.76. Our results for $\mathrm{pH}$ and acidity agree generally with those proposed by the French standard for the Dornic acidity of raw milk, indicating a pH between 6.6 and 6.8 for cow's milk [34]. The measurement of milk density in these areas ranged from 1.0310 to 1.0318 . The normal density of milk is situated normally between 1.030 and 1.035 according to Barboza and Miranda [35]. When the values of the densities are under 1.030 , milk samples are wetted causing by consequent a decrease in their densities. Our findings for physical criteria are in general similar to those previously described by Labioui et al.[20] in Mnasra region in Gharb (West-North of Morocco). Moreover, our findings are slightly higher than those reported by Srairi et al.[4] in Rabat-sale region for densities (minimum: 1.0279, maximum: 1.0290) and also for temperature (minimum: $8.8^{\circ} \mathrm{C}$, maximum: $29.1^{\circ} \mathrm{C}$ ). The dispersion of the values found for chemical and physical criteria among samples in these studied areas could be explained by the effect of a variety of factors such the health and age status of the cows, their stage of lactation, environmental conditions and herd management practices.

When milk composition quality in Morocco is compared with that reported in some regions in Algeria. Our findings for fat and for total solids contents stay higher respectively with what was reported by Benlahcen et al.[36] in areas of Sidi Bachir, Messerghine, Fleurus and Gdyel in Oran region $(31.3,28.3,22.6$ and $24.5 \mathrm{~g} / \mathrm{l}$ respectively for fat and 118, 96, 92 and $100 \mathrm{~g} / \mathrm{l}$ respectively for dry extract). In contrast, our finding showed low values of acidity in comparison to those reported by Benlahcen et al.[36] (with a minimum of 17 and a maximum of $20 \mathrm{D}^{\circ}$ ) while our findings obtained for $\mathrm{pH}$ and density are generally in concordance with those obtained in different areas of Oran (a minimum of 6.3 and a maximum of 6.7 for $\mathrm{pH}$ and a minimum of 1.029 to a maximum of 1.032 for density) [36]. On the other hand and compared to other studies in Algeria, precisely in Mitidja area (located in Algeria city region), Furthermore our findings concerning fat, protein, density, total solids and solids no-fat stay higher than what also reported in Mitidja in Algeria region (around of 31 $\mathrm{g} / \mathrm{l}, 29.1 \mathrm{~g} / \mathrm{l}, 1.03,118 \mathrm{~g} / \mathrm{l}$ and $87 \mathrm{~g} / \mathrm{l}$ were recorded respectively for fat, protein, density, dry matter and defatted dry matter) [37]. Taken at whole, these results reveal the presence of significant variation between Moroccan and Algerian milk characteristics.

Adding to that, our findings for total solids, fat content, density and acidity remain also higher to values reported by Gargouri et al.[13] in Tunisian dairy herds (10.82\% for total solids, $30.2 \mathrm{~g} / \mathrm{l}$ for fat content, 20, $75 \mathrm{D}^{\circ}$ and 1.029 for density). This variation could be related to the adopted farming system and effect of conditions adopted for cow breeding between the three Maghrebian countries in North of Africa.

The alcohol test is generally utilized as a rapid and simple indicator of milk freshness. According to this test, all milk samples tested were normal at $74 \%$. This test is also considered a practical means of determination the propensity of milk for heat coagulation. The other importance of this test that is allowed the detection of abnormal milk, such as colostrum, milk from animals in late lactation, milk from animals suffering from mastitis and milk in which mineral balance has been disturbed.

\section{CONCLUSION}

The present study showed a notable variation in some chemical and physical criteria such as in case of protein rate, fat content, total solids, acidity and density in the different studied areas but all measured parameters are in the range of national and international standards. The recorded physical parameters indicate in general, although indirectly, the presence of good hygienic milk criteria.

\section{ACKNOWLEDGMENT}

This work is supported by scientific research council of Sultan Moulay Slimane University. 


\section{TRANSPARENCY DECLARATIONS}

None to declare.

\section{REFERENCES}

[1] Belkadi, N., directeur de l'Association nationale des éleveurs bovins, membre de la Fédération Fimalait, pendant la 11ème édition du Salon international de l'agriculture au Maroc (SIAM) 2016 qui se déroulait à Meknès, Maroc.

[2] Sayouti, S.N., Ait El Mekki, A. Le Plan Maroc Vert et l'autosuffisance alimentaire en produits de base à l'horizon 2020. Alternatives Rurales (3),2015.

http://alternativesrurales.org/wpcontent/uploads/Numero3/AltRur3PM VetAutosuffisanceAli entairePourImp.pdf (access date: 17.11.17)

[3] Ounine, K., Rhoutaisse, A. and El Halou, N.E. 2004. Caractérisation bactériologique du lait cru produit dans les étables de la région du Gharb. Al awamia, 109-110 : 187-204.

[4] Srairi, M.T., Hasni Alaoui, I., Hamama, A. et Faye, B. 2005. Relations entre pratiques d'élevage et qualité globale du lait de vache en étables suburbaines au Maroc. Revue de Médecine Véterinaire. 156 (3) : 155-162.

[5] Taybi, N.O., Arfaoui A., Fadli M. 2014. Evaluation of microbiological quality of raw milk in the region of Gharb, Morocco. International Journal of Innovation Science and Research, 9; 487-93

[6] Mchiouer, K,. Bennani, S,. El-Gendy, N.S., Meziane, M. 2017. Evaluation of the hygienic quality of raw cow's milk in Oujda city Morocco. Biosciences Biotechnology Res Asia, 14: 587-91.

[7] Afif, A., Faid, M., Najimi, M. 2007. Effects of breeding and hygienic practices on raw cow milk quality in Tadla area, Morocco. Livestock Research for Rural Development, 19 (12).

[8] Afif, A., Faid, M., Najimi, M. 2008. Qualité microbiologique du lait cru produit dans la région de Tadla au Maroc. Reviews in Biology and Biotechnology, 7: 2-7

[9] Ferdous, N.. Hnini, R., Chigr, F,. Najimi, M. 2017. Hygienic Quality of Raw Cow Milk Produced by Smallholder Dairy Farmers in Beni Mellel area in Morocco. World Journal of Research and Review (WJRR), 5 : 09-16.

[10] Ferdous, N., Hnini, R., Merzouki, M., Bahi, L., Chigr, F., Najimi, M. 2017. Microbiological Characteristics of Raw Cow Milk in Beni Mellal Area (Morocco). International Journal of Science and Engineering Applications, Volume 6 Issue 10, ISSN-2319-7560.

[11] [Angulo, F.I., Le Jeune, J.T., Rajala-Schultz, P.J. 2009. Unpasteurized milk : A continued public health threat. Clinic Infection Disease, 48 93-100

[12] Le Jeune, J.T., Rajala-Schultz, P.J. 2009. Unpasteurized milk: A continued public health threat. Food safety, 48: 93-100.

[13] Gargouri, A., Hamed, H., Ben alia, B., Elfeki, A., Gdoura, R. 2014. Evaluation of Tunisian milk quality in dairy herds: Inter-relationship between chemical, physical and hygienic criteria. Animal Science Journal,

Doi: 10.1111/asj.12180

[14] Fox, P.F. 1997. Advanced Dairy Chemistry: Lactose, Water, Salts and Vitamins 2nd edn. Chapman and Hall, London.

[15] Michel, V., Hauwuy, A., Chamba, J.F. 2001. La flore microbienne de laits crus de vache: diversité et influence des conditions de production. Le Lait, 81: 575-592.

[16] Sraïri, M.T., Moudnib, J., Rahho, L., Hamama, A. 2006. How do milking conditions affect the hygienic quality of raw milk? Case study from Moroccan dairy farms. Livestock Research and Rural Development 18(7), Article \#97.

[17] Guiraud, J.P. 2003. Microbiologie alimentaire. Edition Dunod, Paris; P: 651-662.

[18] Cherkaoui, F.Z., El Iamani, A., El Mansouri, L. 2004. Développement et pratique de la fertigation dans le périmètre irrigué du Tadla. IPI regional workshop on Potassium and Fertigation development in West Asia and North Africa; Rabat, Morocco.

[19] El Harti, A., Lhissou, R., Chokmani, K., Ouzemou, J., Hassouna, M., Bachaoui, E., El Ghmari, A. 2016. Spatiotemporal monitoring of soil salinization in irrigated Tadla Plain (Morocco) using satellite spectral indices. International Journal of Applied Earth Observation and Geoinformation, 50: 64-73

[20] Labioui, H., El moualdi, L., Ben zakour, A., El yachioui, M., Berny, E., Ouhssine, M. 2009. Étude physicochimique et microbiologique de lait. Bulletin de la Société de pharmacie de Bordeaux , 148: 7-16.

[21] AFNOR (Association Française de Normalisation). 1980. Lait. Détermination de la matière sèche. NF VO4 207, In AFNOR (Ed.), Recueil de normes françaises. Laits et produits laitiers. Méthodes d'analyse. Paris : Normalisation française, P: 33-34.
[22] AFNOR (Association Française de Normalisation). 1993. Contrôle de la qualité des produits alimentaires- Lait et produits laitiers : analyses physicochimiques. Paris La Défense : AFNOR, 4e éd., P: 581

[23] AFNOR (Association Française de Normalisation). 2001. Lait Détermination de la teneur en matière grasse - Méthode gravimétrique (méthode de référence). NF EN ISO 1211, P: 21.

[24] N.M. 08.4.008 (Norme Marocaine NM 08.4.008) : Laits et produits dérivés, détermination de la teneur en matière grasse. Méthode acido-butyrométrique (Dite de Gerber). Ministère du Commerce et de l'Industrie, Service de Normalisation Industrielle Marocaine (SNIMA).

[25] Bérard, H.L., Rosell, J.M., Turgeon, J. 1936. L'influence de l'alimentation des vaches laitières sur la production de lait de bonne qualité industrielle. Le Lait, INRA Editions, 16 (160), pp.1068-1083. <hal-00895258>

[26] Houssin, B., Chenais, F., Forêt, A. 2003. Renc. Rech. Ruminants, 10 219-222

[27] Houssini, B., Chenais, F., Hardy, A. 2004. Effect of the kind of nitrogen supplement of maize silage diet on the fat composition and the organoleptic and nutritionnal qualities of butters and camembert cheeses. Renc. Rech. Ruminants, 11

[28] Bassbasi, M., Hirri, A., Oussama, A. 2013. Caractérisation physico chimique du lait cru dans la région de Tadla-Kelaa au Maroc: Application de l'analyse exploratoire. International Journal of Innovation and Applied Studies, ISSN 2028-9324, 2: 512-517.

[29] Gonzalo, C., Blanco, A., Beneitez, E., Juarez, M T., Martinez, Linage, B., Ariznabarreta, A. 2005. Qualité physico-chimique et hygiénique du lait de brebis chez les troupeaux du bassin de castilla-Léon (Espagne). Rens. Rech. Ruminants, 12, 401.

[30] Rouillle, B., Lamy, J.M., Plouzini, D., Brunschwig, P., Saulas, L. L'ensilage de sorgho sucrier BMR assure de bonnes performances chez les vaches laitières.

[31] Wilkinson, M.G., Meehan, H., Stanton, C., Cowan, C. 2001. Marketing Cheese with a Nutrient Content. IDF Bulletin, Internationa Dairy Federation, Brussels, 363: 39-45.

[32] Czerniewicz, M., Kruk, A., Kietczewska, K. 2006. Storage stability of raw milk subjected to vibration. Polish Journal of Food and Nutrition Sciences $15 / 56,65-70$

[33] Hamama, A. 2002. Hygiène et prophylaxie dans les étables laitières .cours de Formation des techniciens de l'office régionale de Mis en valeur agricole L'haouz. Marrkech. pp 10-25, 62-71,80-110.

[34] Harper, W.J., Hall, C.W. 1976. Dairy technology and engineering. The AVI publishing company, Inc., Westport, Connecticut, Etats-Unis

[35] Barbosa, M., Miranda, R. 1986. Physico-Chemical and Microbio-logical Characteristics of Goat Milk in Portugal. Bull. IDF., 202: 84-89.

[36] Benlahcen, K., Mouloudi, F., Kihal, M. 2013. Study of the microbiological and physicochemical quality of raw milk from cows exposed to environmental pollutants in the region of West Algeria International Journal of Environmental Engineering Science and Technology Research, 1: 229-240, Available online at www.ijestr.org

[37] Ouchene-Khelifi, N.A., Lafri, M., Ferrouk, M., Ouchene, N. Physicochemical analysis of raw milk of Prim'holstein cows in the region of Mitidja in Algeria. 